\title{
Konaklama İşletmelerinin Kurumsal İletişim Yönetimi Çerçevesinde Ticari Fuarlara Katılımına Yönelik Bir Model Önerisi*
}

\section{A Model Proposal for Accommodation Establishment's Trade Fairs Participation within the Framework of Corporate Communication Management}

\author{
Ömer Çoban, ${ }^{\text {a,** }}{ }^{*}$ ülay Güzel ${ }^{\text {b }}$ \\ ${ }^{a}$ Dr. Öğr. Üyesi, Batman Üniversitesi, Turizm İşletmeciliği ve Otelcilik Yüksekokulu, Turizm ve Otel İşletmeciliği Bölümü, 72100, Batman/Türkiye. \\ ORCID: 0000-0002-2316-4468

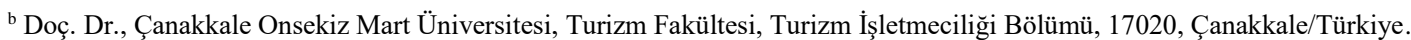 \\ ORCID: 0000-0002-3323-3287
}

\section{MAKALE BILGİSI}

\section{Makale Geçmişi:}

Başvuru tarihi: 23 Kasım 2017

Düzeltme tarihi: 22 Aralık 2017

Kabul tarihi: 30 Aralık 2017

\section{Anahtar Kelimeler:}

Ticari Fuarlar

Turizm Fuarları

Kurumsal İletişim Yönetimi

Konaklama İşletmeleri

Model Önerisi

\section{ARTICLE INFO}

Article history:

Received 23 November 2017

Received in revised form 22 December 2017

Accepted 30 December 2017

\section{Keywords:}

Trade Shows

Travel Fairs

Corporate Communication Management

Accommodation Establishments

Model Proposal

\section{ÖZ}

Çalışmada, konaklama işletmelerinin kurumsal iletişim yönetimi çerçevesinde turizm fuarlarına katılımına yönelik bir model önerisi geliştirilmesi amaçlanmıştır. Araştırmanın evrenini Travel Turkey ve EMITT (Doğu Akdeniz Uluslararası Turizm ve Seyahat Fuarı) fuarına katılan 410 konaklama işletmesi oluşturmuştur. Araştırmada veriler fuar esnasında yüz yüze anket uygulaması ve katılımcı gözlem tekniği ile toplanmıştır. Araştırma sonucunda konaklama işletmelerinin kurumsal iletişim davranış göstermesi üzerindeki en önemli faktörün fuara katılım şekli olduğu tespit edilmiştir. Fuara tekil olarak katılım gösteren işletmelerin, fuara katılım sürecinde kurumsal iletişim davranışlarını daha başarılı bir şekilde sergiledikleri tespit edilmiştir. Araştırma sonucunda konaklama işletmelerinin turizm fuarlarına katılımına yönelik üç temel aşamadan (fuar öncesi, fuar esnası ve fuar sonras1) oluşan bir model geliştirilmiştir.

\section{Giriş}

Fuarlar işletmelere, müşterileri ve tedarikçileriyle toplantılar yapma ve ilişki geliştirme imkânı sunmaktadır (Rice ve
Almossawi, 2002: 150). Bunun yanı sıra fuarlar işletmeler için sadece satış yapabilecekleri bir alan olmayıp, aynı zamanda piyasaya sundukları ürün ve hizmetleri test edebilecekleri, müşteri davranışlarını araştırabilecekleri,

\footnotetext{
* Bu çalışma, 2014 yılında Çanakkale Onsekiz Mart Üniversitesi Sosyal Bilimler Enstitüsü tarafindan kabul edilen "Konaklama İşletmelerinin Kurumsal İletişim Yönetimi Çerçevesinde Ticari Fuarlara Katılımına Yönelik Bir Model Önerisi” adlı Doktora tezinden türetilmiştir.

** Sorumlu yazar/Corresponding author.

e-posta: ocoban@yahoo.com
} 
yeni dağıtım kanalı üyeleri bulabilecekleri ve paydaşlarıyla işbirliği kurabilecekleri bir ortamdır (Palumbo ve Herbig, 2002: 94). Fuarların odağında ağırlıklı olarak işletmenin ürettiği ürünler ve müşteriler olduğu için, fuarlar sıklıkla pazarlama başlığı altında ele alınan bir konu haline gelmiştir. (Palumbo ve Herbig, 2002; Rice ve Almossawi, 2002; Tanner ve Chonko, 2002; Hansen, 2004; Wu vd., 2008). Bununla birlikte işletmelerin fuar alanında müşterileri, potansiyel müşterileri, tedarikçileri, dağıtım kanalı üyeleri başta olmak üzere birçok paydaşıyla iletişim kurduğu kaçınılmaz bir gerçektir. $\mathrm{Bu}$ nedenle fuarları sadece pazarlama başlığı altında incelemek yanlış olmasa bile eksik olacaktır.

İşletmelerin fuara katılım amaçları incelendiğinde; fuar alanında potansiyel müşterilerle (Carman, 1968; Bonoma, 1983; Kerin ve Cron, 1987; Shipley vd., 1993; Hansen, 1996; Blythe, 1997; Blythe, 1999; Ramsaran-Fowdar, 2004; Bathelt ve Schuldt, 2008), tedarik zinciri üyeleriyle (Shipley vd., 1993; Hansen, 1996; Blythe, 1997; Herbig vd., 1998; Blythe, 1999; Smith vd., 2003; Ramsaran-Fowdar, 2004; Lee vd., 2010), diğer işletmeler ve ziyaretçilerle (Lee vd., 2010), kilit karar vericilerle iletişime geçmenin ön plana çıktığı görülmektedir. Bu etkiletişim sırasında işletmeler kurumsal kimlik ögelerini işletme standında sergileyerek paydaşlarıyla etkileşime geçmekte ve paydaşları nezdinde kurumsal imajlarını geliştirmeye çalışmaktadırlar (Bonoma, 1983; Kerin ve Cron, 1987; Shipley vd., 1993; Blythe, 1997; Herbig vd., 1998; Blythe, 1999; Munuera ve Ruiz, 1999; Ramsaran-Fowdar, 2004; Celep, 2008). Bu nedenle birçok çalışmada fuarlara ilişkin faaliyetler, halkla ilişkiler ve kurumsal iletişim kapsamında da değerlendirmektedir (Dekimpe vd., 1997; Kirchgeorg vd., 2009; CordenteRodriguez vd., 2011; Geigenmüller ve Bettis-Outland, 2012). İşletmelerin her yıl ticari fuarlara katılmak için ilgili departman bütçelerinin önemli bir kısmını ayırdıkları (Seringhaus ve Rosson, 2001: 878) ve fuar alanında kurulan iletişimin tüm paydaşlar nezdinde işletmenin imajına ve itibarına etki ettiği düşünüldüğünde; sürecin planlı ve sistematik olarak yürütülmesi gerekliliği ortaya çıkmaktadır. $\mathrm{Bu}$ yüzden işletmelerin fuar alanındaki iletişim çabalarını, işletmenin "kurumsal iletişim" sürecinden ayrı düşünmek olanaksiz hale gelmektedir.

Çalışmada konaklama işletmelerinin kurumsal iletişim yönetimi çerçevesinde turizm fuarlarına katılımına yönelik model önerisi geliştirilmesi amaçlanmıştır. Çalışmada veriler anket ve katılımcı gözlem tekniği ile toplanmıştır. Konaklama işletmelerinin kurumsal iletişim yönetimi çerçevesinde turizm fuarlarına katılımına yönelik bir model önerisi geliştirilmeye çalışılmasının bir dizi amacı bulunmaktadır. Alanyazın taraması yapıldığında, ticari fuarlara ilişkin farklı şekillerde ele alınmış çalışmalara rastlanmıştır. Ancak alanyazında yapılan çalışmalar incelendiğinde konaklama işletmeleri ve turizm fuarları özelinde yapılmış az sayıda çalışma tespit edilmiştir (Kozak, 2005; Milner, 2009; Yuksel ve Voola, 2010; Lee vd., 2010; Rittichainuwat ve Mair, 2012). Bu çalışmalarda ise ağırlıklı olarak turizm fuarlarına katılan katılımcıların ve ziyaretçilerin motivasyonları (Kozak, 2005; Milner, 2009; Yuksel ve Voola, 2010; Lee vd., 2010; Rittichainuwat ve Mair, 2012) belirlenmeye çalışılmıştır. Bu bağlamda çalışmada ilk olarak konaklama işletmelerinin kurumsal iletişim yönetimi bağlamında turizm fuarlarına katılım sürecinin yönetimine ilişkin alanyazındaki araştırma boşluğunun (research gap) doldurulması amaçlanmaktadır. Çalışma sonucunda elde edilen veriler 1şı̆̆ında ortaya konulan model önerisi ile ise konaklama işletmelerinin etkili kurumsal iletişim yönetimi için turizm fuarlarına katılım süreçlerine ilişkin bir yol haritası çizilmeye çalışılmıştır. Böylece işletmelerin ciddi bütçeler ayırdıkları (Kerin ve Cron, 1987: 87; Gopalakrishna vd., 1995: 75; Poorani, 1996: 78) fuarlara katılım sürecinde kaynakları daha etkin kullanabilecekleri düşünülmektedir.

\section{Alanyazın Taraması}

Alanyazında ticari fuarlarla ilgili yapılmış birçok araştırma bulunmaktadır. Gerçekleştirilen bu çalışmalarda fuarlar genellikle pazarlama başlığı altında ele alınmakta ve fuarların pazarlama iletişimi karmasının bir elemanı olduğu vurgulanmaktadır (Browning ve Adams, 1988; Pizam, 1990; Tanner, 1994; Gopalakrishna vd., 1995; Ponzurick, 1996; Sharland ve Balogh, 1996; Blythe, 1997; Dekimpe vd., 1997; Shoham, 1999; Smith ve Smith, 1999; Palumbo ve Herbig, 2002; Rice ve Almossawi, 2002; Tanner ve Chonko, 2002; Hansen, 2004; Wu vd., 2008). Bu araştırmalarda yapılan fuar tanımlarında ise daha çok fuarın satış yapma fonksiyonu üzerinde durulmakta, fuarların çok eski bir pazarlama kurumu olduğu ve pazarlama faaliyetlerini bünyesinde barındırdığı vurgulanmaktadır (Florio, 1994: 269; Gregory ve Breiter, 2001: 65). Bu görüşe göre fuarlar, ürün ve hizmetlerin tutundurulmasında pazarlama iletişimi elemanı olarak ele alınmaktadır (Pinar vd., 2002: 33; Smith vd., 2004: 63; Chiou vd., 2007: 33). Ancak bazı yazarlar fuarları, halkla ilişkiler ve kurumsal iletişim kapsamında da değerlendirmektedir (Dekimpe vd., 1997: 55; Kirchgeorg vd., 2009: 68; Cordente-Rodriguez vd., 2011: 1; Geigenmüller ve Bettis-Outland, 2012: 429).

Ticari fuarlar üzerine yapılan çalışmalar incelendiğinde iki temel hususun ön plana çıktığı görülmektedir. Bunlardan ilki, işletmelerin fuara katılımının "süreç yönetimi" kapsamında ele alınmasıdır (Ely, 1994; Vanderleest, 1994; Gopalakrishna vd., 1995; Gopalakrishna ve Lilien, 1995; Rosson ve Seringhaus, 1995; Herbig vd., 1998; Tanner, 2002; Tanner ve Chonko, 2002; Ramsaran-Fowdar, 2004; Lee ve Kim, 2008; Ling-Yee, 2010; Tanford vd., 2012). Bu çalışmalarda fuara katılım sürecindeki faaliyetler (1) fuar öncesi, (2) fuar esnas1 ve (3) fuar sonrası faaliyetler olarak sınıflandırmış ve her bir süreçte yapılması gerekenler tek tek belirtilmiştir (Ely, 1994; Vanderleest, 1994; Herbig vd., 1998; Tanner, 2002; Tanner ve Chonko, 2002; RamsaranFowdar, 2004; Fu vd., 2007; Lee ve Kim, 2008; Ling-Yee, 2010). Öyle ki, Tanner (2002: 231) işletmelerin fuara katılım sürecine yönelik bir model geliştirmiştir. Tanner (2002) tarafından geliştirilen model incelendiğinde, fuara katılım amaçlarının pazarlama eksenli olmasından modelin pazarlama anlayışı çerçevesinde oluşturulduğu anlaşılmaktadır. Ayrıca Fu vd. (2007), Tanner (2002) tarafından geliştirilen modeli baz alarak daha gelişmiş bir model ortaya koymuşlardır. Bu modelde de fuara ilişkin faaliyetler; fuar öncesi, fuar esnası ve fuar sonrası temelinde incelenmiştir.

İkinci husus alanyazındaki birçok çalışmada fuar faaliyetlerinin "satış odaklı ve satış odaklı olmayan faaliyetler" olmak üzere iki başlık altında ele alınmasıdır (Bonoma, 1983: 75-83; Kerin ve Cron, 1987: 91; Shoham, 1992; 339; Shoham, 1999: 46). Bu çalışmalarda satış odaklı 
faaliyetler içerisinde; yeni ürün/hizmetleri tanıtmak, yeni ürün/hizmetlere ilişkin fikir almak, mevcut ya da potansiyel müşterilere satış yapmak, yeni ürünleri test etmek, yeni satış kanalları bulmak yer almaktadır. Diğer taraftan satış odaklı olmayan faaliyetler içerisinde ise pazarla ilgili yeni olasılıkları belirlemek, rekabetçi bilgiler toplamak, mevcut müşterilere hizmet vermek/ onların sorunlarını çözmek, tedarikçi ilişkilerini yönetmek, stratejik işbirliklerine karar vermek, kurumsal morali ve imajı arttırmaya çalışmak bulunmaktadır (Bonoma, 1983: 75-83; Kerin ve Cron, 1987: 91; Shoham, 1992; 339; Shoham, 1999: 46). Bu noktada fuara satış odaklı katılan işletmelerin kurumsal kimlik veya imajdan ziyade satış yapma amacını ön plana çıkardıkları söylenebilir (Cavanaugh, 1976: 101).

\section{Yöntem}

\subsection{Evren ve Örneklem}

Araştırmada evreni, Türkiye'de faaliyet gösterip 05-08 Aralık 2013 tarihleri arasında Travel Turkey ve 30 Ocak-2 Şubat 2014 tarihleri arasında EMITT fuarına katılan konaklama işletmelerinden oluşmaktadır. 05-08 Aralık 2013 tarihleri arasında düzenlenen Travel Turkey fuarına toplam 778 katılımcı iştirak etmiş ve katılımcıların \%21'i (166 katılımcı) konaklama işletmelerinden oluşmuştur (Travel Turkey, 2017). 30 Ocak-2 Şubat 2014 tarihleri arasında EMITT fuarına ise toplam 1089 katılımcı kurum ve kuruluş iştirak etmiştir. $\mathrm{Bu}$ kurum ve kuruluşlar katılımeı profili temelinde analiz edildiğinde, oteller ve tatil köyleri \%22,4 (yaklaşık 244 katılımcı) ile ilk sırada yer almaktadır (EMITT, 2017). Bahsi geçen iki fuara toplam 410 konaklama işletmesinin katıldı̆̆ 1 tespit edilmiştir. Diğer bir ifadeyle çalışma evreninin toplam 410 konaklama işletmesinden oluştuğu ifade edilebilir.

Araştırmada gözlem ve anket teknikleri kullanılarak veri toplanmıştır. Gözlem tekniği ile Travel Turkey ve EMITT fuarlarına iştirak eden konaklama işletmelerinden bizzat fuara katılım gösterilerek fuar alanında veri toplanmıştır. Gözlem tekniği ile veri toplanırken çalışma evreninin tamamına ulaşılmaya çalışılmıştır. Ancak buna rağmen zaman kısitından dolayı toplam 373 (\%91) konaklama işletmesinden gözlem tekniği ile veri toplanabilmiştir. Gözlem verilerinin \%30'u (112) Travel Turkey, \%70'i ise (261) EMITT fuarından toplanmıştır. Anket tekniği ile konaklama işletmelerinin stant yöneticilerinden veri toplanmıştır. Anket tekniği ile de ana kütlenin tamamına ulaşılmaya çalışılmıştır. Buna rağmen, bazı stant yöneticilerinin ankete katılmak istememeleri ve zaman kısıtı vb. faktörler nedeniyle ana kütlenin tamamindan anket tekniği ile veri sağlanamamıştır. Fuarlara katılan 310 konaklama işletmesinden anket toplanmıştır. Toplanan anketlerin 8'inde eksik gözelerin fazla olması nedeniyle, bu anketler değerlendirmeye alınmamış ve değerlendirme toplam 302 anket üzerinden gerçekleştirilmiştir. Anketlerin \%30'u (91) Travel Turkey fuarından toplanmış olup, \% 70’i (211) ise EMITT fuarına katılan konaklama işletmelerinden toplanmıştır. Diğer taraftan EMITT fuarı tarih itibariyle Travel Turkey fuarından sonra gerçekleştiği için, EMITT fuarında veri toplama işlemi gerçekleştirilirken daha önce Travel Turkey fuarına katılım gösteren ve veri toplanan işletmelerden veri toplanmamıştır.

\subsection{Veri Toplama Tekniğgi ve Analizi}

Anket formu ve gözlem formu oluşturma sürecinde öncelikli olarak yazın taraması gerçekleştirilmiştir. Yazın taramasında, belirlenen araştırma problemine ilişkin oluşturulacak ölçüm araçları içerisinde kullanabilecek ifadeler ve sorular saptanmaya çalışılmıştır. Bu çerçevede yerli ve yabancı yazında birçok çalışma incelenmiştir. İncelenen çalışmalar içerisinden anket ve gözlem formunda yer alması gereken ifadeler ve sorular madde havuzuna atılmış ve taslak formlar oluşturulmuştur. Oluşturulan formlar uzman görüşünün alınması maksadıyla, Türkiye'de faaliyet gösteren tüm fuar düzenleyici şirketlere e-posta yoluyla gönderilmiş ve toplam 25 şirketten geri dönüş sağlanmıştır. Alınan geri bildirimler değerlendirmeye alınarak anket ve gözlem formu üzerinde gerekli değişiklikler yapılmıştır. 15 Temmuz- 30 Temmuz 2013 tarihleri arasında anket ve gözlem formları daha önce turizm fuarlarına katılım gösteren 12 konaklama işletmesinin yöneticilerine uygulanarak ön test yapılmıştır. Ön test sonucunda anket ve gözlem formuna son şekli verilmiştir.

Hazırlanan anket formu iki bölümden oluşmaktadır. Birinci bölümde işletme özelliklerini ortaya koymaya yönelik 12 adet kapalı uçlu ifadenin yanı sıra 6 adet açık uçlu soru yer almaktadır. İkinci bölümde ise konaklama işletmelerinin fuar katılım öncesinde, esnasında ve sonrasında kurumsal iletişim yönetimi ekseninde sergilediği davranışları ölçen 69 adet ifadeye yer verilmiştir. İfadelerin 30 tanesi fuar öncesi, 25 tanesi fuar esnası, 14 tanesi ise fuar sonrası işletmelerin kurumsal iletişim davranışlarını ölçmeye yönelik oluşturulmuştur. İfadeler 5'li Likert tipi ölçeğe göre hazırlanmış olup, "1= Hiçbir Zaman, 2= Çok Nadir, 3= Bazen, 4= Çok Sik, 5= Her Zaman" şeklinde dizayn edilmiştir. Gözlem formunda ise işletmenin fuar esnasındaki kurumsal iletişime yönelik davranışlarını ölçmeye yönelik 13 adet soruya yer verilmiştir. Fuar esnasında işletmelere yönelik tespit edilen diğer unsurlar ise gözlem formunda "diğer gözlemler" başlığı altına not edilmiştir.

Geri dönüşü sağlanan anket formlarından elde edilen veriler Minitab 17 ve SPSS 13.0 istatistik paket programlarında değerlendirilmiştir. Elde edilen verilerin betimleyici istatistikleri, ölçeklerin güvenirlikleri SPSS paket programı ile analiz edilmiştir. Değişkenler arası ilişkileri belirlemek üzere ise sıralı lojistik regresyon modeli kullanılarak 3 farklı model oluşturulmuş ve veriler Minitab 17 paket programında analiz edilmiştir. Çalışmada gözlem tekniği ile elde edilen veriler betimsel analize tabi tutulmuştur.

\section{Bulgular ve Yorumlar}

\subsection{Gözlem Tekniği Verilerinin Analizi ve Bulguların Yorumlanmas1}

Gözlem tekniği yoluyla veriler, 05-08 Aralık 2013 tarihleri arasında İzmir Enternasyonal Fuar alanında gerçekleştirilen Travel Turkey ve 30 Ocak - 2 Şubat 2014 tarihleri arasında İstanbul Beylikdüzü TÜYAP fuar alanında gerçekleştirilen EMITT fuarına katılım gösterilerek toplanmıştır. Niteliği itibariyle "katılımlı gözlem" türlerinden "gözlemci olarak katılım" (Agafonoff, 2006: 118) gerçekleştirilerek veriler toplanmıştır. Veri toplama sırasında önceden hazırlanan gözlem formu kullanılmış ve işletme stantlarına ilişkin fotoğraflar çekilmiştir. 
Gözlem tekniği ile toplanan veriler incelendiğinde konaklama işletmelerinin turizm fuarlarına farklı şekillerde katılım gösterdikleri saptanmıştır. Konaklama işletmelerinin fuarlara tekil katılım (individual booths), şemsiye katılım (joint booths) olmak üzere farklı iki şekilde katılım gösterdikleri saptanmıştır. Tekil katılım, bir konaklama işletmesinin herhangi bir işletmeye ya da örgüte bağlı olmaksızın, fuara katılım ücreti kendisi tarafından ödenecek şekilde fuar alanında bir yer kiralaması ve kiraladığı alanda tek başına stant açmasıdır. Şemsiye katılım, tekil katılıma göre daha karmaşık bir yapıya sahiptir. Şemsiye katılımda işletmeler başka bir işletmenin altında veya birlik, belde ya da destinasyon standının altında fuara iştirak etmektedirler. Konaklama işletmelerinin sunmuş olduğu hizmetlerin dağıtım sürecinde üstlenmiş olduğu aracı rolüyle önemli aktörlerden biri olan seyahat acentelerinin açmış oldukları standın bir bölümünde, yapmış oldukları anlaşma çerçevesinde konaklama işletmesine yer vermesi en çok gözlemlenen şemsiye katılım şekli olmuştur. Bir diğer şemsiye katılım modeli ise konaklama işletmesinin faaliyet göstermiş olduğu destinasyonun açmış olduğu stantta kendine yer edinmesidir. Son olarak konaklama işletmeleri kurmuş oldukları sivil toplum örgütleri ya da birliklerin altında fuara katılım gösterebilmektedir.

İşletmelerin tekil katılım göstermelerinin her ne kadar yüksek maliyetli olduğu düşünülse de standın bir bütünlük içinde olduğu ve kurumsal kimlik öğelerinin (kurumsal renkler, logo, slogan vb.) daha rahat bir şekilde sergilendiği gözlemlenmiştir. Yapılan araştırmalarda fuarlara tekil katılımın şemsiye katılıma göre kurumsal imaj yaratma sürecinde daha yüksek performans sağladığını göstermektedir (Skallerud, 2010: 259). Diğer bir ifadeyle, işletmelerin fuara tekil katılım göstererek ziyaretçilerin ve diğer paydaşların zihninde daha iyi bir imaj çizdiği ifade edilebilir (Skallerud, 2010: 264). Bu bağlamda konaklama işletmelerinin turizm fuarlarına tekil katılım göstermeleri, fuara katılım sürecini kurumsal iletişim sürecinin bir parçası olarak ele aldıklarının bir göstergesi olarak karşımıza çıkmaktadır. Tekil katılımda işletmeler stant alanının ve tipinin belirleyicisi konumundadır. Oysa, şemsiye katılımda işletmeler, anlaşmaları gereği sadece acente, birlik veya destinasyon yöneticilerinin kendilerine gösterdikleri stant içi alanı kullanabilmektedirler. Diğer taraftan şemsiye katılımda stant alanın belirlenme süreci yine işletme dişı aktörler tarafından gerçekleştirilmektedir. $\mathrm{Bu}$ nedenle şemsiye katılım gösteren işletmelerin stantlarda kendi görsellerine, sloganlarına, kurumsal renklerine yer veremedikleri gözlemlenmiştir. Tekil katılımda ise işletmeler stant alanının tek hâkimi olduklarından dolayı, stant tasarımı ve dizaynını kendi istekleri doğrultusunda gerçekleştirebilmekte ve böylece stant alanı içerisinde kurumsal kimlik öğelerine yer verebilmektedirler. Başka bir ifadeyle, şemsiye katılım sürecinde işletmenin fuara şemsiyesi altında katılım göstermiş olduğu acenta, birlik ve destinasyonun; tekil katılımda ise işletmenin kendi kurumsal kimlik öğeleri ön plana çıkmaktadır. Buradan hareketle işletmelerin tekil katılım göstererek kurumsal imajlarını yönetme sürecinde daha başarılı olabilecekleri söylenebilir.

Katılım şekilleri tanıtım materyalleri bağlamında değerlendirildiğinde, tekil katılım gösteren konaklama işletmelerinin daha zengin bir yelpazeyle işletmeyi temsil ettikleri ifade edilebilir. Şemsiye katılım sürecinde işletmelerin logolarına stant ile bütünleşik olmayacak şekilde yer verilmiş ve genellikle tanıtım aracı olarak broşürlerden ve afişlerden yararlanılmıştır. $\mathrm{Bu}$ da kurumsal kimliği parçalayıcı bir faktör olarak karşımıza çıkmaktadır. Konaklama işletmelerinin acentelerin altında fuarlara iştirak etmelerinde gözlemlenen bir başka husus, işletmelerin stantlarında acente personeli veya acente tarafından fuarın düzenlendiği bölgeden sağlanan personelin yer aldığ1 gözlemlenmiştir. Personelin k1yafetlerinin ise acente tarafından belirlenen kıyafetlerden oluştuğu söylenebilir. Bu noktada işletmelerin paydaşlar nezdindeki imaj ve itibarının işletmeyi çok iyi tanımayan birine emanet edildiği ifade edilebilir. Diğer taraftan personel kıyafetlerinin kurumsal kimlik öğesinin bir parçası olduğu düşünüldüğünde, bu stantlarda görev alan personelin acentenin kurumsal renklerini bünyesinde barındıran kıyafetleri taşıdığ gözlemlenmiştir.

Yazında birçok yazar işletmelerin fuara katılım amaçlarını satış odaklı amaçlar ve satış odaklı olmayan amaçlar olmak üzere ikiye ayırmıştır (Bonoma, 1983; Kerin ve Cron, 1987). Satış odaklı amaçlar işletmenin fuara katılım sürecini pazarlama faaliyetlerinin bir parçası olarak ele aldığının bir göstergesidir. Diğer taraftan satış odaklı olmayan amaçlar ekseninde fuara iştirak eden işletmelerin, süreci kurumsal iletişim sürecinin bir alt öğesi olarak değerlendirdiği ifade edilebilir. Fuara farklı şekillerde katılım gösteren işletmelerin ortak amaçları olduğu söylenebilir. İşletmeler, kendilerini tanıtmanın yanı sıra, yeni üretmiş oldukları ürün ve hizmetler hakkında bilgi vermek, yeni bağlantılar kurmak, rakipler ve tedarikçiler hakkında bilgi toplamak, gelişmeleri takip etmek vb. amaçlarla fuarlara katılmaktadırlar. Elde edilen gözlem bulgularından hareketle fuara tekil katılım ile iştirak eden işletmelerin ise temel amaçlarının salt satış odaklı amaçlar olmadığı gözlemlenmiştir. $\mathrm{Bu}$ işletmeler yüksek maliyetleri göz önüne alarak fuara katılmakta ve işletmeye ait kurumsal kimlik öğelerini bağımsız olarak sergileyerek paydaşlar zihninde olumlu bir imaj yaratmaya çalışmaktadır. Diğer taraftan şemsiye katılım gösteren işletmeler maliyetleri düşük tutmaya çalışarak çeşitli birlik, destinasyon ya da acenta altında fuara katılmakta ve işletmenin üretmiş olduğu hizmetlerin satışını gerçekleştirmeye ve yeni bağlantılar kurmaya çalışmaktadır.

\subsection{Anket Tekniği Verilerinin Analizi ve Bulgularının Yorumlanması}

Anket formunda araştırmaya katılan işletmelerin özelliklerini belirlemeye yönelik 18 adet soru yöneltilmiştir. Araştırma kapsamındaki konaklama işletmelerinin özelliklerine ilişkin bulguların frekans ve yüzde dağılımları Tablo 1' de verilmektedir.

Tablo 1. İşletmelerin Özelliklerine İlişkin Frekans ve Yüzde Analizi Sonuçları

\begin{tabular}{lcclcc}
\hline Mülkiyet Türü & $\mathrm{f}$ & $\%$ & İşletme Türü & $\mathrm{f}$ & $\%$ \\
\hline Doğrudan Yat. & 284 & 94 & Resort Otel & 145 & 48 \\
Yönetim Söz. & 10 & 3,3 & Şehir Oteli & 88 & 29,2 \\
Diğer & 8 & 2,7 & Diğer & 69 & 22,8 \\
\hline İşletme Tipi & $\mathrm{f}$ & $\%$ & Katılım Şekli & $\mathrm{f}$ & $\%$ \\
\hline Bağımsız Otel & 190 & 62,9 & Şemsiye & 184 & 60,9 \\
Zincir Otel & 112 & 37,1 & Tekil & 118 & 39,1 \\
\hline Yıldız Sayıs1 & $\mathrm{f}$ & $\%$ & Faaliyet Süresi & $\mathrm{f}$ & $\%$ \\
\hline 4 Yıldız & 88 & 29,1 & 10 y1l & 105 & 34,8 \\
5 Yildız & 164 & 54,3 & $11-20$ yıl & 154 & 50,9 \\
Diğer & 50 & 16,6 & 21 y1l & 43 & 14,3
\end{tabular}




\begin{tabular}{lcclcc}
\hline \multirow{2}{*}{ Stanttaki Personel Sayısı } & f & $\%$ & $\begin{array}{l}\text { Stanttaki Yön. } \\
\text { Sayısı }\end{array}$ & f & $\%$ \\
\hline $1-3$ & 232 & 76,8 & 1 & 217 & 71,9 \\
$4-6$ & 66 & 21,8 & 2 & 69 & 22,8 \\
7 & 4 & 1,4 & 3 & 16 & 5,3 \\
\hline Personel Kay. & $\mathrm{f}$ & $\%$ & Stant Alanı & $\mathrm{f}$ & $\%$ \\
\hline İsletme Per. & 125 & 41,4 & 10 & 186 & 61,7 \\
Dışarıdan Per. & 177 & 58,6 & $11-25$ & 89 & 29,4 \\
& & & 26 & 27 & 8,9 \\
\hline Fuarlara Hazırlık Süresi & $\mathrm{f}$ & $\%$ & Departman & $\mathrm{f}$ & $\%$ \\
\hline 1-3 ay & 273 & 90,4 & Satış \& Paz. & 212 & 70,2 \\
4-6 ay & 26 & 8,6 & Kurumsal İlet. & 68 & 22,5 \\
7-9 ay & 3 & 1 & Diğer & 22 & 7,3 \\
\hline
\end{tabular}

Turizm fuarlarına katılan konaklama işletmelerinin büyük ölçüde bağımsız $(\% 62,9)$, doğrudan yatırım ile kurulmuş (\%94), Akdeniz, Ege ve Marmara bölgelerinde faaliyet gösteren $(\% 91), 4$ ve 5 yıldızlı $(\% 83,4)$ resort ve şehir otellerinden $(\% 77,2)$ oluştuğu tespit edilmiştir. İşletmelerin önemli bir kısmı fuarlara şemsiye katılım $(\% 60,9)$ göstermiştir. Fuara katılım sürecinin ise ağırlıklı olarak satış ve pazarlama departmanı tarafindan organize edildiği $(\% 70,2)$ ve yine fuara katılım bütçesinin bu departman bütçesinden ayrıldığı $(\% 67,2)$ bulgulanmıştır. İşletmelerin fuara katılım süreçleriyle ilgili bir başka önemli bulgu; işletmelerin \% 41,4'ünün stantta işletme personeline, \%58,6'sının ise fuarın gerçekleştiği bölgeden istihdam edilen geçici personele görev verdiğidir. Ayrıca gözlem sonuçlarında stantta kendi personeline görev veren işletmelerin tekil katılım gösteren konaklama işletmeleri olduğu tespit edilmiştir.

Araştırmada nicel veri analizine öncelikle ölçeklerin güvenilirliklerin araştırılmasıyla başlanmıştır. Fuar öncesi kurumsal iletişim yönetimi davranışlarına ilişkin ölçeğin güvenirliği 0,947; fuar esnası kurumsal iletişim davranışlarına ilişkin ölçeğin güvenirliği 0,936; fuar sonrası kurumsal iletişim davranışlarına ilişkin ölçeğin güvenirliği ise 0,914 olarak hesaplanmıştır. Ölçeklerde yer alan ifadelerin ortalamalarının birbirine eșit olup olmadıkları Hotelling $T^{2}$ seçeneği ile değerlendirilmiş ve anlamlı bulunmuştur. Buna göre; fuar öncesi kurumsal iletişim yönetimi davranışları ölçeğinde Hotelling $\mathrm{T}^{2}=3053,18$; $\mathrm{F}=95,49 ; \quad \mathrm{p}=0,0001$; fuar esnas1 kurumsal iletişim davranışları ölçeğinde Hotelling $\mathrm{T}^{2}=3262,048 ; \mathrm{F}=125,53$; $\mathrm{p}=0,0001$; fuar sonrası kurumsal iletişim davranışları ölçeğinde Hotelling $\mathrm{T}^{2}=524,296 ; \mathrm{F}=38,72 ; \mathrm{p}=0,0001$ olarak hesaplanmıştır. Bu sonuç, ifadelerin işletmeler tarafindan aynı yaklaşım ile algılandığı ve toplum tarafından benzer sonuçlar verecek şekilde hazırlandığını göstermektedir. Ölçekte yer alan ifadelerde soru bütün korelasyonlara bakılmıs ve negatif korelasyona sahip herhangi bir ifadeye rastlanmamıştır. Dolayısıyla ölçekte çıkartıldığında güvenilirliği yükselten herhangi bir ifade yoktur.

Siralı lojistik regresyon analizinde kurulan modellerde bağımlı değişken olarak konaklama işletmelerinin "fuar öncesi, fuar esnası ve fuar sonrası" kurumsal iletişime yönelik davranışları belirlenmiştir. Bağımlı değişkenlerin sıralı yapısından dolayı araştırmada sıralı lojistik regresyon analizi kullanılmıştır. Bağımlı değişkenlerin üzerinde bağımsız değişkenlerin etkilerinin olup olmadığ incelenmiş ve Tablo 2, Tablo 3, Tablo 4 elde edilmiştir. Tüm modellerde paralellik sağlanmış olup, paralellik varsayımı gerçekleşmiştir. Yapılandırılan modellerin uygunluğunu belirlemek için uygulanan Pearson Ki-Kare modeli uygunluk testi sonuçları (Pearson ve Deviance) anlamlı bulunmuş ve her modele ait istatistiklere ilgili tablolarda yer verilmiştir.

Sıralı lojistik regresyonda değişkenler modele konulmadan önce her bir ölçekteki sorulara verilen yanıtlar (puan) toplanmış, soru sayısına bölünmüştür. Böylelikle her bir birime ait ortalama puan değeri elde edilmiş ve modele bağımsız değişken olarak dâhil edilmiştir. Bağımlı değişken olarak ortalama puanlar 5 kategori olacak şekilde ölçümlendirilmiştir. Bunun için 1-1,799=1 (Hiçbir Zaman); $1,80-2,599=2$ (Çok Nadir); 2,60- 3,399=3 (Bazen); 3,404,199=4 (Çok Sık); 4,20- 5,000= 5 (Her Zaman) kategorileri oluşturulmuştur. Araştırmada toplam 3 model kurulmuştur. Minitab paket programında en fazla dokuz bağımsız değişkenin bağımlı değişken üzerindeki etkileri incelenebildiğinden dolayı, kurulan modellerde bağımlı değişkenler üzerinde etkisi olma olasılığı yüksek olan bağımsız değişkenler modele dâhil edilmiştir.

Kurulan ilk modelde konaklama işletmelerinin "fuar öncesi kurumsal iletişim davranışlarının" incelenmesi sırasında bağımsız değişken olarak, konaklama işletmelerinin fuara katılım şekli (tekil-şemsiye), yıldız sayısı, faaliyet süresi, kiraladıkları stant alanı, stantta çalışan personel sayısı, yönetici sayısı, stantta çalışan personelin hangi kaynaktan temin edildiği ve fuara hazırlık süreleri modele dâhil edilmiştir. Model 1'e ilişkin sonuçlar Tablo 2'de verilmiştir.

Tablo 2. Model 1: Fuar Öncesi Kurumsal İletişim Davranışlarına İlişkin Sıralı Lojistik Regresyon Sonuçları

\begin{tabular}{|c|c|c|c|c|c|}
\hline Değişken & Ölçüm & $\mathrm{N}$ & & & \\
\hline Fuar Öncesi & $\begin{array}{l}\text { Çok Nadir } \\
\text { Bazen } \\
\text { Çok Sik } \\
\text { Her Zaman } \\
\text { Toplam }\end{array}$ & $\begin{array}{l}16 \\
138 \\
91 \\
57 \\
302 \\
\end{array}$ & & & \\
\hline Değişkenler & Katsay 1 & St. Sapma & Z & $\mathrm{P}$ & $\begin{array}{l}\text { Odds } \\
\text { Oran1 }\end{array}$ \\
\hline$\overline{\text { Konstant(1) }}$ & $-12,0367$ & 1,61403 & $-7,46$ & 0,000 & \\
\hline Konstant (2) & $-7,62766$ & 1,53060 & $-4,98$ & 0,000 & \\
\hline Konstant (3) & $-3,46792$ & 1,21135 & $-2,86$ & 0,004 & \\
\hline Katılım Şekli & 3,94913 & 0,698581 & 5,65 & 0,000 & 51,89 \\
\hline Y1ldız Sayısı & $-0,129021$ & 0,152234 & $-0,85$ & 0,397 & 0,88 \\
\hline Faaliyet Süresi & 0,0045136 & 0,0129329 & 0,35 & 0,727 & 1,00 \\
\hline Stant Alanı & $-0,0105808$ & 0,0229773 & $-0,46$ & 0,645 & 0,99 \\
\hline Personel Say. & $-0,308330$ & 0,187588 & $-1,64$ & 0,100 & 0,73 \\
\hline Yönetici Say. & 0,0846754 & 0,187588 & 0,35 & 0,730 & 1,09 \\
\hline Personel Kay. & 1,60078 & 0,473718 & 3,38 & 0,001 & 4,96 \\
\hline $\begin{array}{l}\text { Fuara Haz. } \\
\text { Süresi }\end{array}$ & $-0,130568$ & 0,449995 & $-0,29$ & 0,772 & 0,88 \\
\hline
\end{tabular}

\section{Uyum Testleri}

\begin{tabular}{lcrc}
\hline Metot & $\mathrm{Ki}^{2}$ & $\mathrm{DF}$ & $\mathrm{P}$ \\
Pearson & 1506,29 & 699 & 0,000 \\
Deviance & 339,62 & 699 & 1,000
\end{tabular}

Deviance

339,62

6991,000

Log-olasılik $=-214,055$

Test that all slopes are zero: $\mathrm{G}=290,458 ; \mathrm{DF}=9 ; \mathrm{P}-\mathrm{V}$ alue $=0,000$

Bağımlı değişkenin "işletmelerin fuar öncesi kurumsal iletişim davranışları" olduğu modelde, işletmelerin fuara katılım şekilleri 0,0001; personeli hangi kaynaktan temin ettikleri ise 0,001 düzeyinde anlamlı bulunmuştur. Diğer bağımsız değişkenlerin modele katkısı ise anlamlı bulunmamıştır. Buna göre, konaklama işletmelerinin fuara tekil katılım göstermesi fuar öncesi işletme davranışlarının kurumsal iletişim yönetimi çerçevesinde olma olasılığını 
51,89 kat arttırmaktadır $(\mathrm{p}=0,0001)$. Diğer taraftan fuar alanında stantta görev alan personelin işletme personeli olması da işletmenin fuar öncesi davranışlarının kurumsal iletişim çerçevesinde sürdürülmesini 4,96 kat arttırma olasılığına sahip olduğu tespit edilmiştir $(p=0,001)$.

Model 2'de konaklama işletmelerinin “fuar esnasında sergilemiş oldukları kurumsal iletişim davranışları" bağımlı değişken olarak alınmıştır. Diğer taraftan modele bağımsız değişken olarak ise Model 1'deki gibi konaklama işletmelerinin fuara katılım şekli, yıldız sayısı, faaliyet süresi, kiraladıkları stant alanı, stantta çalışan personel sayıs1, yönetici sayısı, stantta çalışan personelin hangi kaynaktan temin edildiği ve fuara hazırlık süreleri dâhil edilmiştir. Model 2'nin sonuçlarına Tablo 3'de yer verilmiştir.

Tablo 3. Model 2: Fuar Esnası Kurumsal İletişim Davranışlarına İlişkin Sıralı Lojistik Regresyon Sonuçları

\begin{tabular}{|c|c|c|c|c|c|}
\hline Değişken & Ölçüm & $\mathrm{N}$ & & & \\
\hline \multirow[t]{6}{*}{ Fuar Esnas1 } & $\begin{array}{l}\text { Hiçbir } \\
\text { Zaman }\end{array}$ & 3 & & & \\
\hline & Çok Nadir & 44 & & & \\
\hline & Bazen & 122 & & & \\
\hline & Çok Sik & 98 & & & \\
\hline & Her Zaman & 35 & & & \\
\hline & Toplam & 302 & & & \\
\hline Değişkenler & Katsayı & St. Sapma & $\mathrm{Z}$ & $\mathrm{P}$ & $\begin{array}{l}\text { Odds } \\
\text { Oran1 } \\
\end{array}$ \\
\hline$\overline{\text { Konstant(1) }}$ & $-16,4937$ & 1,74304 & $-9,46$ & 0,000 & \\
\hline Konstant (2) & $-13,3169$ & 1,64162 & $-8,11$ & 0,000 & \\
\hline Konstant (3) & $-9,08139$ & 1,48731 & $-6,11$ & 0,000 & \\
\hline Konstant (4) & $-4,35114$ & 1,18789 & $-3,66$ & 0,000 & \\
\hline Katılım Şekli & 4,51970 & 0,686989 & 6,58 & 0,000 & 91,81 \\
\hline Y1ld1z Say1sı & $-0,171525$ & 0,158953 & $-1,08$ & 0,281 & 0,84 \\
\hline Faaliyet Süresi & 0,0046142 & 0,0130569 & 0,35 & 0,724 & 1,00 \\
\hline Stant Alanı & $-0,0003904$ & 0,0206978 & $-0,02$ & 0,985 & 1,00 \\
\hline Personel Say. & $-0,297818$ & 0,191998 & $-1,55$ & 0,121 & 0,74 \\
\hline Yönetici Say. & 0,0934215 & 0,244997 & 0,38 & 0,703 & 1,10 \\
\hline Personel Kay. & 1,55704 & 0,469583 & 3,32 & 0,001 & 4,74 \\
\hline$\underline{\text { Fuara Haz. Süresi }}$ & $-0,252060$ & 0,421778 & $-0,60$ & 0,550 & 0,78 \\
\hline \multicolumn{6}{|l|}{ Uyum Testleri } \\
\hline \multicolumn{2}{|l|}{ Metot } & $\mathrm{Ki}^{2}$ & $\mathrm{DF}$ & & $\mathrm{P}$ \\
\hline \multirow{2}{*}{\multicolumn{2}{|c|}{$\begin{array}{l}\text { Pearson } \\
\text { Deviance }\end{array}$}} & 1520,48 & 68 & 0, & 000 \\
\hline & & 333,17 & 68 & 1, & 000 \\
\hline \multicolumn{6}{|c|}{$\begin{array}{l}\text { Log-olasilik }=-214,360 \\
\text { Test that all slopes are zero: } G=289,848 ; \mathrm{DF}=8 ; \mathrm{P}-\text { Value }= \\
0,000\end{array}$} \\
\hline
\end{tabular}

Bağımlı değişkenin konaklama işletmeleri tarafından "fuar esnasında sergilenen kurumsal iletişim davranışları" olduğu modelde, işletmelerin fuara katılım şekilleri 0,0001 ; personeli hangi kaynaktan temin ettikleri ise 0,001 düzeyinde anlamlı bulunmuştur. Diğer bağımsız değişkenlerin modele katkısı ise Model 1'deki gibi anlamlı bulunmamıştır. Buna göre, konaklama işletmelerinin fuara tekil katılım göstermesi fuar esnası işletme davranışlarının kurumsal iletişim yönetimi bağlamında olma olasılığını 91,81 kat arttırmaktadır ( $\mathrm{p}=0,0001)$. Ayrıca fuar alanında stantta görev alan personelin işletme personeli olması da işletmenin fuar esnası davranışlarının kurumsal iletişim çerçevesinde sürdürülmesini 4,74 kat arttırma olasılığına sahip olduğu saptanmıştır ( $\mathrm{p}=0,001)$.
Kurulan üçüncü modelde konaklama işletmelerinin "fuar sonrası kurumsal iletişim davranışları" bağımlı değişken olarak kabul edilmiştir. Modele bağımsız değişken olarak ise Model 1 ve Model 2'deki gibi, konaklama işletmelerinin fuara katılım şekli, yıldız sayısı, faaliyet süresi, kiraladıkları stant alanı, stantta çalışan personel ve yönetici sayısı, stantta çalışan personelin hangi kaynaktan temin edildiği ve fuara hazırlık süreleri dâhil edilmiştir. Model 3'e ait sonuçlara Tablo 4'te yer verilmiştir.

Tablo 4. Model 3: Fuar Sonrası Kurumsal İletișim Davranıșlarına İlişkin Sıralı Lojistik Regresyon Sonuçları

\begin{tabular}{|c|c|c|c|c|c|}
\hline Değişken & Ölçüm & $\mathrm{N}$ & & & \\
\hline \multirow[t]{6}{*}{ Fuar Sonras1 } & $\begin{array}{l}\text { Hiçbir } \\
\text { Zaman }\end{array}$ & 1 & & & \\
\hline & Çok Nadir & 46 & & & \\
\hline & Bazen & 112 & & & \\
\hline & Çok Sik & \multirow{2}{*}{$\begin{array}{l}57 \\
86\end{array}$} & & & \\
\hline & Her Zaman & & & & \\
\hline & Toplam & 302 & & & \\
\hline Değişkenler & Katsayı & St. Sapma & $\mathrm{Z}$ & $\mathrm{P}$ & $\begin{array}{l}\text { Odds } \\
\text { Oran1 }\end{array}$ \\
\hline Konstant(1) & $-12,7618$ & 1,56077 & $-8,18$ & 30,000 & \\
\hline Konstant (2) & $-8,62334$ & 1,20331 & $-7,17$ & 70,000 & \\
\hline Konstant (3) & $-5,70209$ & 1,16047 & $-4,91$ & 0,000 & \\
\hline Konstant (4) & $-3,49646$ & 1,05621 & $-3,31$ & 0,001 & \\
\hline Katılım Şekli & 4,01904 & 0,527941 & 7,61 & 0,000 & 55,65 \\
\hline Y1ld1z Sayıs1 & $-0,0614017$ & 0,145256 & $-0,42$ & 20,673 & 0,94 \\
\hline Faaliyet Süresi & $-0,0086918$ & 0,0127966 & $-0,68$ & 3) 0,497 & 0,99 \\
\hline Stant Alanı & 0,0058935 & 0,0218752 & 0,27 & 0,788 & 1,01 \\
\hline Personel Say. & $-0,298725$ & 0,186053 & $-1,61$ & l 0,108 & 0,74 \\
\hline Yönetici Say. & 0,0186851 & 0,257188 & 0,07 & 0,942 & 1,02 \\
\hline Personel Kay. & 0,0454885 & 0,402732 & 0,11 & 0,910 & 1,05 \\
\hline Fuara Haz. Süresi & 0,0665535 & 0,377203 & 0,18 & 0,860 & 1,07 \\
\hline \multicolumn{6}{|l|}{ Uyum Testleri } \\
\hline \multicolumn{2}{|l|}{ Metot } & $\bar{L}$ & $\overline{\mathrm{DF}}$ & $\mathrm{P}$ & \\
\hline \multirow{2}{*}{$\begin{array}{l}\text { Pearson } \\
\text { Deviance }\end{array}$} & \multicolumn{2}{|c|}{864,760} & 12 & 0,867 & \\
\hline & 464 & 4,080 & 12 & 1,000 & \\
\hline
\end{tabular}

Bağımlı değişkenin "fuar sonrasında sergilenen kurumsal iletişim davranışları" olduğu modelde, ilk iki modelden farklı olarak sadece işletmelerin fuara katılım şekilleri anlamlı bulunmuştur ( $p=0,0001)$. Model 3 'te diğer bağımsız değişkenlerle birlikte personelin hangi kaynaktan temin edildiği de anlamlı bulunmamıștır. Buna göre, konaklama işletmelerinin fuara tekil katılım göstermesi fuar sonrası işletme davranışlarının kurumsal iletişim yönetimi bağlamında olma olasılığını 55,65 kat arttırma olasılığına sahiptir $(\mathrm{p}=0,0001)$.

Kurulan üç modelde de, konaklama işletmelerinin turizm fuarlarına tekil olarak katılmasının kurumsal iletişim yönetimi çerçevesinde davranışlar sergileme olasılığını arttırdığı sonucuna ulaşılmıştır. Bu sonuç gözlem tekniği ile elde edilen bulguları doğrulamaktadır. Konaklama işletmelerinin fuara tekil olarak katılım göstermeleri, süreci tek başına yönetmelerini sağlayacaktır. Diğer taraftan bu işletmeler stantta kendi kurumsal kimlik öğelerine daha rahat yer vererek kurumsal imajlarına katkıda bulunabileceklerdir. Ayrica Model 1 ve Model 2'de personelin hangi kaynaktan temin edildiğinin etkili olduğu saptanmıştır. Diğer bir ifadeyle, konaklama işletmelerinin fuar öncesi ve fuar esnasında kurumsal iletişim yönetimi bağlamında davranış 
sergileme olasılığının, stantta görev alan personelin, işletme personeli olması durumunda arttığı söylenebilir. Personel seçiminin fuar sonrası kurumsal iletişim davranışları üzerinde etkisinin anlamlı çıkmaması ise fuar sonrasında ağırlıklı olarak değerlendirme faaliyetlerine yer verildiği ve bu sürecin yönetim kademesi tarafından yürütülmesiyle açıklanabilir.

\subsection{Modelin Kurgulanmas1}

Yazın taramasında elde edilen bilgiler değerlendirildiğinde, çalışma kapsamında geliştirilecek modelin, fuar öncesi, fuar esnası ve fuar sonrası olmak üzere üç evreden oluşması gerektiği sonucuna ulaşılmıştır. Ancak çalışma konaklama işletmelerinin turizm fuarlarına katılımını ele aldığından dolay1, bu evrelerde modele özgü faaliyetlere yer verilmesi gerektiği sonucu karşımıza çıkmaktadır. Diğer taraftan çalışmada, fuarlara katılım süreci "kurumsal iletişim yönetimi” kapsamında değerlendirilmektedir. Bu nedenle fuara katılan konaklama işletmelerinin öncelikli amaçlarının "satış odaklı olmayan" amaçlar çerçevesinde şekillenmesi gerektiği ifade edilebilir. Yazın taraması sonucunda modelin "fuar öncesi, fuar esnası ve fuar sonrası" olmak üzere üç evreden oluşması ve fuara katılma amaçlarının "satış odaklı olmayan amaçlar" çerçevesinde şekillenmesi gerektiği sonucuna ulaşılmıştır.

Şekil 1'de çalışma kapsamında geliştirilen modele yer verilmiştir. Konaklama işletmelerinin kurumsal iletişim yönetimi bağlamında turizm fuarlarına katılmalarına yönelik geliştirilen modelde öncelikli olarak işletmenin amaçlarına yer verilmiştir. Modelde ilgili amaçlar "satış odaklı olmayan" amaçlar olarak ele alınmıştır. İşletmelerin satış odaklı olmayan amaçlara öncelik vermesi, işletmelerin fuara katılımını kurumsal iletişim anlayışı çerçevesinde gerçekleştirmesinin bir gereği olduğu söylenebilir. Ancak, işletmeler aynı zamanda üretmiş olduğu yeni ürün ve hizmetleri fuar alanında tanıtabilir ve satış yapmaya çalışabilir. Buna rağmen fuar faaliyetlerini kurumsal iletişim kapsamında ele alabilmek için işletmelerin satış odaklı olmayan amaçlara odaklanması gerekmektedir.

Konaklama işletmelerinin fuara katılma amaçlarını satış odaklı olmayan amaçlar ekseninde belirledikten sonra fuara katılım şekline karar vermeleri gerekmektedir. İşletmelerin fuara tekil katılımı her ne kadar ilk bakışta maliyeti yüksek bir katılım şekli olarak değerlendirilse de kurumsal iletişim yönetimi çerçevesinde tercih edilmesi gereken katılım şekli olarak karşımıza çıkmaktadır. Konaklama işletmeleri, tekil katılım göstererek fuara katılım sürecini başından sonuna kadar kendi kontrolleri altında tutabileceklerdir.

Konaklama işletmeleri turizm fuarlarına katılım şekline karar verdikten sonra uygulama sürecine geçmektedirler. $\mathrm{Bu}$ süreç; fuar öncesi, fuar esnası ve fuar sonrası olmak üzere üç evreden oluşmaktadır. Bu evrelerde işletmeler tarafindan hayata geçirelecek faaliyetler belirlenirken ise her bir evreye ait ölçekte 3.50 ve üzeri puan alan ifadelere yer verilmiştir. Diğer taraftan, işletmelerin fuara katılım sürecini iyi bir şekilde yönetmeleri gerekmektedir. $\mathrm{Bu}$ nedenle modelde yönetim sürecinin işlevleri olan "planlama, örgütleme, yöneltme, koordinasyon, denetim" (Ürper ve Besler, 2013: 5) faaliyetlerine de yer verilmiştir.

Konaklama işletmelerinin etkili kurumsal iletişim yönetimi için turizm fuarlarına katılımına yönelik geliştirilen modelde izlenen süreç sonrasında, işletmeler kurumsal iletişim performansına ulaşmaktadırlar. İşletmeler fuar öncesi faaliyetler sırasında belirlemiş oldukları performansa ulaşıp ulaşmadığını kontrol etmekte ve eğer istedikleri sonuçlara ulaşamadılarsa sorunun hangi evreden kaynaklandığını tespit etmek durumundadırlar. Böylece bir sonraki fuar katılım sürecinde benzer hatalar tekrarlanmayacak ve işletmeler istenen performansa ulaşacaklardır.

\section{Sonuç ve Değerlendirme}

Çalışmada konaklama işletmelerinin kurumsal iletişim yönetimi çerçevesinde turizm fuarlarına katılımı incelenmiş ve bu amaçla model önerisi geliştirilmiştir. Modelde işletmelerin fuara katılımlarında satış odaklı olmayan amaçları önceliğe almasının kurumsal iletişim yönetimi bağlamında fuarlara katılmasının ön şartı olduğu vurgulanmıştır. Bununla birlikte gözlem ve anket tekniği verilerinin analizi sonucunda işletmelerin kurumsal iletişim yönetimi performansını belirleyen hususların başında; işletmelerin fuara tekil katılım göstermeleri ve stant personelini iç kaynaklardan temin etmelerinin geldiği sonucuna ulaşılmıştır. Alanyazında yapılan öncül araştırmalarda da fuarlara tekil katılımın fuar alanındaki paydaşlar nezdinde kurumsal imaj yaratma potansiyelinin daha yüksek olduğu görülmektedir (Skallerud, 2010: 259264). Benzer şekilde stantta görev alan personelin de paydaşlar üzerinde işletme lehine etki yarattığ anlaşılmaktadır. Bu nedenle işletmelerin; standın konumunu, stant dizaynını, standın genel görüntüsünü, stantta görev alan personel ve personelin kıyafetini titizlikle seçmesi gerekmektedir.

Konaklama işletmelerinin turizm fuarlarına kurumsal iletişim yönetimi bağlamında katılım sürecini daha başarılı yönetebilmeleri için fuar öncesi, fuar esnası ve fuar sonrası sergileyeceği davranışlar önem taşımaktadır. Buna göre konaklama işletmeleri ilk olarak fuara katılım öncesinde hedef kitle analizi yapmalıdır. Bu süreçte fuara katılım amacının sadece tanıtım ve satış yapmak değil aynı zamanda paydaşlar nezdinde işletmeye ilişkin olumlu bir alg1 yaratmak olduğu gözden kaçırılmamalıdır. Zira bu algının oluşturulması işletmeye, fuar alanında yapmış olduğu satış ve kurmuş olduğu bağlantının çok daha üzerinde getiri sağlayacaktır. Fuar alanında ise paydaşlarla etkili bir şekilde iletişime geçilmelidir. Bu iletişim gerçekleştirilirken tek amaç işletmeye müşteri, tedarikçi ya da aracı kazandırmak değil, aynı zamanda bu paydaşların olumlu izlenimlerini kazandırmak olduğu unutulmamalıdır. Ayrıca işletmeye ilişkin olumlu imaj ve itibar oluşturmak için stant alanında işletmeye ilişkin uygun kurumsal kimlik öğelerine yer verilmelidir. Stantta yer alan tanıtım materyallerinin katılım gösterilen fuara ve hedef kitleye uygun olup olmadığı katılım öncesinde belirlenmelidir. $\mathrm{Bu}$ noktada konaklama işletmelerinin standının, işletmenin butik bir görüntüsü olduğu düşünülerek hareket edilmesi yararlı olacaktır. Bu nedenle konaklama işletmesi için simge haline gelmiş ve görüldüğünde akla o işletmeyi çağrıştıran materyallere stant alanında mümkünse yer verilmelidir. Diğer taraftan, stant personeli işletme personelleri arasından titizlikle seçilmeli ve stantta giyeceği kıyafet işletmenin kurumsal kimlik öğelerinden izler barındırmalıdır. Fuar öncesinde işletmenin fuara katılım amaçları ve fuar esnasında gerekli olabilecek bilgiler stant personeliyle paylaşılmalıdır. 


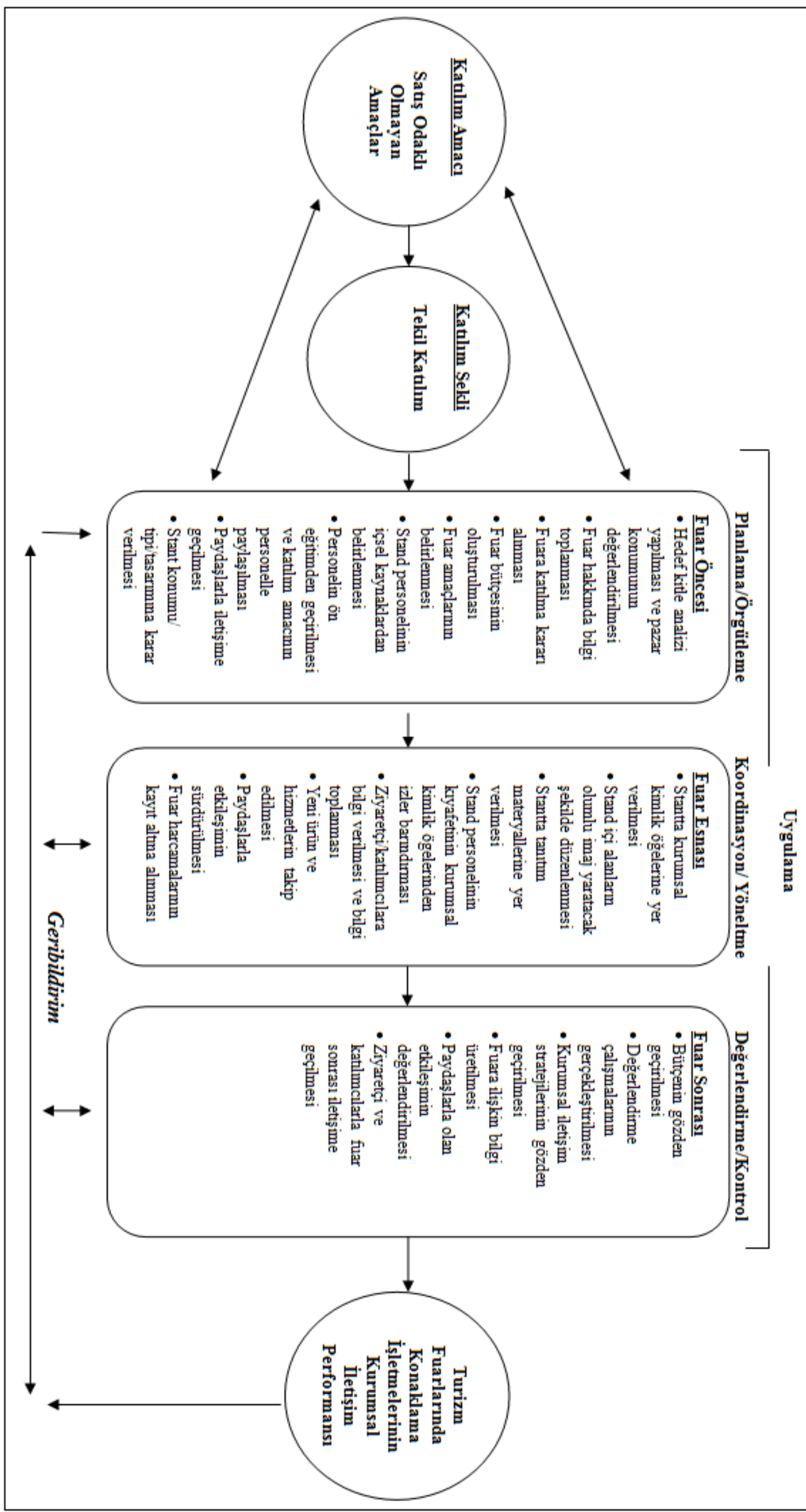

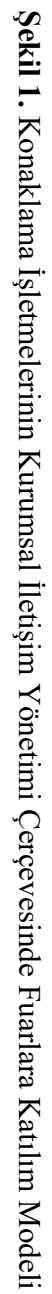


Ziyaretçilerin ve katılımcıların işletme standı ve personelinin görüntüsüne bakarak değerlendirmelerde bulunacağı göz ardi edilmemelidir.

$\mathrm{Bu}$ araştırmada konaklama işletmelerinin turizm fuarlarına kurumsal iletişim yönetimi çerçevesinde katılımlarına yönelik model önerisi geliştirilmiştir. Ancak geliştirilen model henüz öneri aşamasındadır. Dolayısıyla modelin etkin bir şekilde çalışıp çalışmadığı, ancak turizm fuarlarına katılım gösteren konaklama işletmeleri modeli uyguladıktan sonra ölçümlenebilecektir. Diğer taraftan işletmelerin bu model sayesinde başarıya ulaşıp ulaşmadı̆̆ını anlayabilmek için, fuar sonrasında performanslarının ölçümüne yönelik ayrı bir çalışma yapılması gerekmektedir. Gerçekleştirilecek araştırmalarda ele alınacak bir başka konu, konaklama işletmelerin turizm fuarlarına katılımına yönelik kurumsal iletişim stratejilerinin, paydaşların araştırmaya dâhil edilerek değerlendirilmesidir. Diğer bir ifadeyle böyle bir çalışmada veri, sadece konaklama işletmelerinden değil aynı zamanda işletmenin paydaşlarından da toplanarak çalışma geliştirilebilir. Böylece paydaşların işletmelere ilişkin izlenimlerinde yorumların ötesine geçilebilir. Gelecek araştırmalar için başka bir öneri, benzer bir araştırmanın fuara katılım gösteren destinasyonlar bazında gerçekleştirilmesidir. Destinasyonların fuarlara katılımı için birçok kurum ya da kuruluş işbirliği yaparak bir araya gelmektedir. Dolayısıyla bu süreç başlı başına yönetilmesi gereken bir süreçtir. Her bir kurum ya da kuruluşun sorumlulukları belirlenerek, bu sürecin kimin önderliğinde yürütülmesi gerektiğine ilişkin bir çalışma gerçekleştirilebilir. Çalışmada konaklama işletmelerinin kurumsal iletişim yönetimi çerçevesinde turizm fuarlarına katılımı incelenmiş ve bu amaçla model önerisi geliştirilmiştir. Modelde işletmelerin fuara katılımlarında satış odaklı olmayan amaçları önceliğe almasının kurumsal iletişim yönetimi bağlamında fuarlara katılmasının ön şartı olduğu vurgulanmıştır. Bununla birlikte gözlem ve anket tekniği verilerinin analizi sonucunda işletmelerin kurumsal iletişim yönetimi performansını belirleyen hususların başında; işletmelerin fuara tekil katılım göstermeleri ve stant personelini iç kaynaklardan temin etmelerinin geldiği sonucuna ulaşılmıştır. Alanyazında yapılan öncül araştırmalarda da fuarlara tekil katılımın fuar alanındaki paydaşlar nezdinde kurumsal imaj yaratma potansiyelinin daha yüksek olduğu görülmektedir (Skallerud, 2010: 259264). Benzer şekilde stantta görev alan personelin de paydaşlar üzerinde işletme lehine etki yarattığ anlaşılmaktadır. Bu nedenle işletmelerin; standın konumunu, stant dizaynını, standın genel görüntüsünü, stantta görev alan personel ve personelin k1yafetini titizlikle seçmesi gerekmektedir.

Konaklama işletmelerinin turizm fuarlarına kurumsal iletişim yönetimi bağlamında katılım sürecini daha başarılı yönetebilmeleri için fuar öncesi, fuar esnası ve fuar sonrası sergileyeceği davranışlar önem taşımaktadır. Buna göre konaklama işletmeleri ilk olarak fuara katılım öncesinde hedef kitle analizi yapmalıdır. Bu süreçte fuara katılım amacının sadece tanıtım ve satış yapmak değil aynı zamanda paydaşlar nezdinde işletmeye ilişkin olumlu bir algı yaratmak olduğu gözden kaçırılmamalıdır. Zira bu algının oluşturulması işletmeye, fuar alanında yapmış olduğu satış ve kurmuş olduğu bağlantının çok daha üzerinde getiri sağlayacaktır. Fuar alanında ise paydaşlarla etkili bir şekilde iletişime geçilmelidir. Bu iletişim gerçekleştirilirken tek amaç işletmeye müşteri, tedarikçi ya da aracı kazandırmak değil, aynı zamanda bu paydaşların olumlu izlenimlerini kazandırmak olduğu unutulmamalıdır. Ayrıca işletmeye ilişkin olumlu imaj ve itibar oluşturmak için stant alanında işletmeye ilişkin uygun kurumsal kimlik öğelerine yer verilmelidir. Stantta yer alan tanıtım materyallerinin katılım gösterilen fuara ve hedef kitleye uygun olup olmadığı katılım öncesinde belirlenmelidir. $\mathrm{Bu}$ noktada konaklama işletmelerinin standının, işletmenin butik bir görüntüsü olduğu düşünülerek hareket edilmesi yararlı olacaktır. Bu nedenle konaklama işletmesi için simge haline gelmiş ve görüldüğünde akla o işletmeyi çağrıştıran materyallere stant alanında mümkünse yer verilmelidir. Diğer taraftan, stant personeli işletme personelleri arasından titizlikle seçilmeli ve stantta giyeceği kıyafet işletmenin kurumsal kimlik öğelerinden izler barındırmalıdır. Fuar öncesinde işletmenin fuara katılım amaçları ve fuar esnasında gerekli olabilecek bilgiler stant personeliyle paylaşılmalıdır. Ziyaretçilerin ve katılımcıların işletme standı ve personelinin görüntüsüne bakarak değerlendirmelerde bulunacağı göz $\operatorname{ard}_{1}$ edilmemelidir.

$\mathrm{Bu}$ araştırmada konaklama işletmelerinin turizm fuarlarına kurumsal iletişim yönetimi çerçevesinde katılımlarına yönelik model önerisi geliştirilmiştir. Ancak geliştirilen model henüz öneri aşamasındadır. Dolayısıyla modelin etkin bir şekilde çalışıp çalışmadığı, ancak turizm fuarlarına katılım gösteren konaklama işletmeleri modeli uyguladıktan sonra ölçümlenebilecektir. Diğer taraftan işletmelerin bu model sayesinde başarıya ulaşıp ulaşmadığını anlayabilmek için, fuar sonrasında performanslarının ölçümüne yönelik ayrı bir çalışma yapılması gerekmektedir. Gerçekleştirilecek araştırmalarda ele alınacak bir başka konu, konaklama işletmelerin turizm fuarlarına katılımına yönelik kurumsal iletişim stratejilerinin, paydaşların araştırmaya dâhil edilerek değerlendirilmesidir. Diğer bir ifadeyle böyle bir çalışmada veri, sadece konaklama işletmelerinden değil aynı zamanda işletmenin paydaşlarından da toplanarak çalışma geliştirilebilir. Böylece paydaşların işletmelere ilişkin izlenimlerinde yorumların ötesine geçilebilir. Gelecek araştırmalar için başka bir öneri, benzer bir araştırmanın fuara katılım gösteren destinasyonlar bazında gerçekleştirilmesidir. Destinasyonların fuarlara katılımı için birçok kurum ya da kuruluş işbirliği yaparak bir araya gelmektedir. Dolayısıyla bu süreç başlı başına yönetilmesi gereken bir süreçtir. Her bir kurum ya da kuruluşun sorumlulukları belirlenerek, bu sürecin kimin önderliğinde yürütülmesi gerektiğine ilişkin bir çalışma gerçekleştirilebilir.

\section{Kaynakça}

Agafonoff, N. (2006). Adapting ethnographic research methods to ad hoc commercial market research. Qualitative Market Research: An International Journal, 9(2), 115-125.

Bathelt, H., \& Schuldt, N. (2008). Between luminaires and meat grinders: International trade fairs as temporary clusters. Regional Studies, 42(6), 853-868.

Blythe, J. (1997). Does size matter? Objectives and measures at UK trade exhibitions. Journal of Marketing Communications, 3(1), 51-59. 
Blythe, J. (1999). Learning by doing - frequency of exhibiting at UK trade exhibitions. Journal of Marketing Communications, 5(4), 207-221.

Bonoma, T. V. (1983). Get more out of your trade shows. Harvard Business Review, 61(1), 75-83.

Browning, J. M., \& Adams, R. J. (1988). Trade shows: An effective promotional tool for the small industrial business. Journal of Small Business Management, 26(4), 31-36.

Carman, J. M. (1968). Evaluation of trade show exhibitions. California Management Review, 11(2), 35-44.

Cavanaugh, S. (1976). Setting objectives and evaluating the effectiveness of trade show exhibits. The Journal of Marketing, 40(4), 100-103.

Celep, D. S. (2008). Pazarlama İçinde Fuarcılı̆̆ın Yeri, Işletmelerin Fuarcılık Faaliyetine Bakışı ile İlgili Bir Uygulama. (Yayınlanmamış yüksek lisans tezi), Marmara Üniversitesi Sosyal Bilimler Enstitüsü, İstanbul.

Chiou, J. S., Hsieh, C. H., \& Shen, C. C. (2007). Product innovativeness, trade show strategy and trade show performance: The case of Taiwanese global information technology firms. Journal of Global Marketing, 20(2-3), 31-42.

Cordente-Rodriguez, M., Mondéjar-Jiménez, J. A., \& Gázquez-Abad, J. C. (2011). Evolution of fair business performance as a tool of marketing in Spain. The Review of Business Information Systems, 15(5), 1-9.

Dekimpe, M. G., Francois, P., Gopalakrishna, S., Lilien, G. L., \& Van den Bulte, C. (1997). Generalizing about trade show effectiveness: A cross-national comparison. The Journal of Marketing, 61(4), 55-64.

Ely, T. (1994). How to use trade shows in economic development. Economic Development Review, 12(4), 8891.

EMITT (2017). Katılım Istatistikleri. (Erişim: 01.08.2017), http://www.emittistanbul.com/emitt-hakkinda-2/katilimistatistikleri/

Florio, M. (1994). Fair trades by trade fairs: information providing institutions under monopolistic competition. Small Business Economics, 6(4), 267-281.

Fu, H., Yang, G., \& Qi, Y. (2007). Factors affecting trade show effectiveness for Chinese small and medium-sized exporters. International Management Review, 3(3), 8496.

Geigenmüller, A., \& Bettis-Outland, H. (2012). Brand equity in B2B services and consequences for the trade show industry. Journal of Business \& Industrial Marketing, 27(6), 428-435.

Gopalakrishna, S., \& Lilien, G. L. (1995). A three-stage model of industrial trade show performance. Marketing Science, 14(1), 22-42.

Gopalakrishna, S., Lilien, G. L., Williams, J. D., \& Sequeira, I. K. (1995). Do trade shows pay off?. The Journal of Marketing, 59(3), 75-83.
Gregory, S., \& Breiter, D. (2001). Trade show managers: Profile in technology usage. Journal of Convention \& Exhibition Management, 3(3), 63-76.

Hansen, K. (1996). The dual motives of participants at international trade shows: An empirical investigation of exhibitors and visitors with selling motives. International Marketing Review, 13(2), 39-53.

Hansen, K. (2004). Measuring performance at trade shows: Scale development and validation. Journal of Business Research, 57(1), 1-13.

Herbig, P., O’Hara, B., \& Palumbo, F. A. (1998). Trade show: who, what, why. Marketing Intelligence \& Planning, 16(7), 425-435.

Kerin, R. A., \& Cron, W. L. (1987). Assessing trade show functions and performance: An exploratory study. The Journal of Marketing, 51(3), 87-94.

Kirchgeorg, M., Springer, C., \& Kästner, E. (2009). Objectives for successfully participating in trade shows. Journal of Business \& Industrial Marketing, 25(1), 6372.

Kozak, N. (2005). The expectations of exhibitors in tourism, hospitality, and the travel industry: A case study on East Mediterranean Tourism and Travel Exhibition. Journal of Convention \& Event Tourism, 7(3-4), 99-116.

Lee, C. H., \& Kim, S. Y. (2008). Differential effects of determinants on multi-dimensions of trade show performance: By three stages of pre-show, at-show, and post-show activities. Industrial Marketing Management, 37(7), 784-796.

Lee, M. J., Yeung, S., \& Dewald, B. (2010). An exploratory study examining the determinants of attendance motivations as perceived by attendees at Hong Kong exhibitions. Journal of Convention \& Event Tourism, 11(3), 195-208.

Ling-Yee, L. (2010). Antecedents and effect of internet implementation for trade shows. Journal of Business \& Industrial Marketing, 25(4), 272-283.

Milner, L. M. (2009). Consumer behavior at an industrial travel show. Tourism Review, 64(4), 4-11.

Munuera, J. L., \& Ruiz, S. (1999). Trade fairs as services: A look at visitors' objectives in Spain. Journal of Business Research, 44(1), 17-24.

Palumbo, F., \& Herbig, P. A. (2002). Trade shows and fairs: An important part of the international promotion mix. Journal of Promotion Management, 8(1), 93-108.

Palumbo, F., O'Hara, B., \& Herbig, P. (1998). Differences between international and domestic trade show exhibitors. Academy of Marketing Studies Journal, 2(2), $1-14$.

Pinar, M., Rogers, J. D., \& Baack, D. (2002). An examination of trade show participation in a developing country: An exploratory study in Turkey. Journal of Euromarketing, 11(3), 33-52.

Pizam, A. (1990). Evaluating the effectiveness of travel trade shows and other tourism sales-promotion techniques. Journal of Travel Research, 29(1), 3-8. 
Ponzurick, T. G. (1996). International buyers perspective toward trade shows and other promotional methods. Journal of Marketing Theory and Practice, 4(1), 9-19.

Poorani, A. A. (1996). Trade-show management: Budgeting and planning for a successful event. The Cornell Hotel and Restaurant Administration Quarterly, 37(4), 77-84.

Ramsaran-Fowdar, R. (2004). Industrial trade shows: A study of related activities. Indian Institute of Management Bangalore Management Review, 16(3), 4455.

Rice, G., \& Almossawi, M. (2002). A study of exhibitor firms at an Arabian gulf trade show: Goals, selection criteria and perceived problems. Journal of Global Marketing, 15(3-4), 149-172.

Rittichainuwat, B., \& Mair, J. (2012). An exploratory study of attendee perceptions of green meetings. Journal of Convention \& Event Tourism, 13(3), 147-158.

Rosson, P. J., \& Seringhaus, F. R. (1995). Visitor and exhibitor interaction at industrial trade fairs. Journal of Business Research, 32(1), 81-90.

Seringhaus, F. R., \& Rosson, P. J. (2001). Firm experience and international trade fairs. Journal of Marketing Management, 17(7-8), 877-901.

Sharland, A., \& Balogh, P. (1996). The value of nonselling activities at international trade shows. Industrial Marketing Management, 25(1), 59-66.

Shipley, D., Egan, C., \& Wong, K. S. (1993). Dimensions of trade show exhibiting management. Journal of Marketing Management, 9(1), 55-63.

Shoham, A. (1992). Selecting and evaluating trade shows. Industrial Marketing Management, 21(4), 335-341.

Shoham, A. (1999). Performance in trade shows and exhibitions: A synthesis and directions for future research. Journal of Global Marketing, 12(3), 41-57.

Skallerud, K. (2010). Structure, strategy and performance of exhibitors at individual booths versus joint booths. Journal of Business \& Industrial Marketing, 25(4), 259267.

Smith, T. M., \& Smith, P. M. (1999). Distributor and enduser trade show attendance objectives: An opportunity for adaptive selling. Forest Products Journal, 49(1), 2329.

Smith, T. M., Gopalakrishna, S., \& Smith, P. M. (2004). The complementary effect of trade shows on personal selling. International Journal of Research in Marketing, 21(1), 61-76.

Smith, T. M., Hama, K., \& Smith, P. M. (2003). The effect of successful trade show attendance on future show interest: Exploring Japanese attendee perspectives of domestic and offshore international events. Journal of Business \& Industrial Marketing, 18(4-5), 403-418.

Tanford, S., Montgomery, R., \& Nelson, K. B. (2012). Factors that influence attendance, satisfaction, and loyalty for conventions. Journal of Convention \& Event Tourism, 13(4), 290-318.
Tanner, J. F. (1994). Adaptive selling at trade shows. Journal of Personal Selling \& Sales Management, 14(2), 15-23.

Tanner, J. F. (2002). Leveling the playing field: Factors influencing trade show success for small companies. Industrial Marketing Management, 31(3), 229-239.

Tanner, J. F., \& Chonko, L. B. (2002). Using trade shows throughout the product life cycle. Journal of Promotion Management, 8(1), 109-125.

Travel Turkey (2017). Katılımcı Listesi. (Erişim: 01.08.2017), http://www.travelturkeyexpo.com/katilimci_listesi.html

Ürper, Y., \& Besler, S. (2013). İşletme Fonksiyonları. Eskişehir: Anadolu Üniversitesi Açık Öğretim Fakültesi Yayınları.

Vanderleest, H. W. (1994). Planning for international trade show participation: A Practitioner's Perspective. SAM Advanced Management Journal, 59(4), 39-44.

Wu, J., Lilien, G. L., \& Dasgupta, A. (2008). An exploratory study of trade show formation and diversity. Journal of Business-to-Business Marketing, 15(4), 397-424.

Yuksel, U., \& Voola, R. (2010). Travel trade shows: Exploratory study of exhibitors' perceptions. Journal of Business \& Industrial Marketing, 25(4), 293-300. 